Euskal ikerketen aldizkaria | Revue d'études basques |

Revista de estudios vascos | Basque studies review

$14 \mid 2010$

Numéro XIV

\title{
Marinelei abisua : izen ondoko datibo sintagmak izenburuen sintaxian
}

Beatriz Fernández Fernández et Ibon Sarasola

\section{(2) OpenEdition}

\section{Journals}

Édition électronique

URL : https://journals.openedition.org/lapurdum/2270

DOI : $10.4000 /$ lapurdum.2270

ISSN : 1965-0655

Éditeur

IKER

Édition imprimée

Date de publication : 1 octobre 2010

Pagination : 55-75

ISSN : 1273-3830

Référence électronique

Beatriz Fernández Fernández eta Ibon Sarasola, «Marinelei abisua : izen ondoko datibo sintagmak izenburuen sintaxian», Lapurdum [Linean], 14 | 2010, Sarean emana---an 15 septembre 2014, kontsultatu 29 juillet 2022. URL: http://journals.openedition.org/lapurdum/2270 ; DOI: https://doi.org/ 10.4000/lapurdum.2270 


\title{
Marinelei abisua: izen ondoko datibo sintagmak izenburuen sintaxian
}

\author{
Beatriz FERNÁNDEZ \& Ibon SARASOLA \\ UPV/EHU
}

\section{Atarikoak}

Lan honetan izen ondoko datibo sintagmak izango ditugu mintzagai. Datibo sintagma horiek izen ondoko postposizio sintagmekin konparatuko ditugu, datiboaren muineko izaera ezagutzen lagunduko digutelakoan (1 atala). Hitz hurrenkera ez ezik (1.3 atala), batzuk zein besteek -ko lotura hizkiarekin (1.2 atala) eta-(r)en kasu markarekin (2. atala) duten harremana ere aztertuko dugu. Horretarako, gaur egungo datuak erabiltzeaz gain, iturri historikoetara ere joko dugu bereziki bi idazle aztertuz: Lardizabal lehenik (3.1) eta Etxeberri Ziburukoa (3.2) ondoren. Izenburuetan, ergatibo sintagmen erabilera ere ikusiko dugu azkenik (4. atala).

\section{Izen ondoko datiboak izenburuen sintaxian}

Datiboaren inguruko eztabaidan, egiturazko kasutzat hartu dute hura euskalari batzuek, eta postposiziotzat jo dute besteek. Hala, datiboa egiturazko kasutzat jo duten hizkuntzalariek, datiboz markatutako sintagma hori izen sintagma (IS) dela aldarrikatu izan dute eta postposiziotzat jo dutenek, berriz, postposizio sintagma. ${ }^{2}$ Eztabaida honetan, inoiz izen ondoko datibo sintagmak (marinelei abisua bezalakoak) aipatu izan dira, hain zuzen, datiboen jokabidea postposizioen modukoa dela erakusteko (etxera bidea), eta azken batean, datiboak

1. Lan honek, gutariko batek Rutgersen 2007an egin zuen egonaldian du abiapuntua. Gaiaren inguruko eztabaida bertan hasi genuen Mark Bakerrekin batera. Eskerrak eman nahi dizkiogu berari eta eztabaida horri segida eman dioten beste lankide estimatu batzuei: Josu Landa, Patxi Goenaga, Pablo Albizu eta Jon Ortiz de Urbinari. Gramatika jarduna, dudarik gabe, ederragoa da eurei esker. Zeresanik ez, lanaren erantzukizun osoa gurea baino ez da. Lan hau ondoko instituzioen eta ikerketa proiektuen babesean egin ahal izan dugu: Ministerio de Ciencia e Innovaciónen FFI2008-00240/FILO; Agence Nationale de la Rechercheren ANR-07CORP-033, eta Eusko Jaurlaritzaren HM-2009-1-25 eta IT4-14-10.

2. Ez dugu eztabaida xehetasunez jaso nahi hemen, baina kontuan izan, ez dela bi muturretara polarizatzen den eztabaida. Izan ere, oinarrian postposizio sintagmatzat hartzen duten hizkuntzalariek beraiek, Albizuk (2001, 2009) esate baterako, eratorritako IStzat hartzen dute datibo sintagma. Hortaz, aurkako bi bideek badute non aurkitu. 
ere postposizioak direla ebazteko (Albizu 2001). Alabaina, izen ondoko datibo sintagmak aztertzerakoan, datibo guztiak, eta ez batzuk bakarrik, hartu behar dira kontuan, bestela euren alderdi bat baino ezin baita ikusi, beste alderdi arras diferentearen kaltetan. Izan ere, datiboetatik bi datibo mota bereizi behar ditugu: bata behe-datiboak, hots, helburu datiboak nagusiki (nik Joni liburua oparitu diot) eta bestea, goi-datiboak, alegia, esperimentatzaileak (Joni liburua ahaztu zaio) eta jabe edota interes datiboak (denei gogoa ilundu zaie). Bada, guztietatik behedatiboak baino ezin dira izen ondokoak izan (marinelei abisua); goi datiboek ezin baitute bestelako loturarik gabe izen ondokoak izan (*Joni ahaztura, *gogoaren ilunketa denei) -ikus baita Fernández (2007) eta Albizu (2009)-. Izen ondokoak izatea, hortaz, behe-datiboek bakarrik duten ezaugarria da, eta ez, inola ere, datibo guztiek dutena. Horregatik, postposizioen antzeko jokabidea duten datiboak, izatekotan, batzuk baino ez dira; beste batzuek, hots, goidatiboek, ergatiboaren edota absolutiboaren jokabide bera dute: ezin daitezke izen ondokoak izan, eta IS bati laguntzeko, genitibo kasuaz baliatu beharra dute (Jonen ahaztura, denen gogoaren ilunketa). Gainerakoan, behe-datiboek eta postposizioek bateratsu jokatzen badute ere, asimetria nabarmen bat dute -ko lotura hizkiaz den bezainbatean: postposizio sintagmek -ko har dezakete (etxerako bidea) ; datibo sintagmek, aldiz, ez (*marineleiko abisua) (de Rijk 1993; Elordieta 2001). Halaber, -(r)en genitiboaz sortutako modifikatzaileetan, adibidez, artzaintzaren omenaldia diogunean, artzaintza omenaldiaren helburua dela interpreta daiteke, hau da, datiboa nolabait berreskura daiteke genitiboaren bidez; ez, ordea, postposizioak. Azkenik erakutsiko dugu izen ondokoak izan daitezkeen datibo zein postposizio sintagmak eskumatara zein ezkerretara lerra daitezkeela, euskalariak hitz hurrenkera kontuetan bat ez badatoz ere (de Rijk 1993; Euskaltzaindia 1985; Makazaga 1999).

\subsection{Izen ondoko datibo sintagmak: eztabaidaren hastapenak}

Euskalaritzan laurogeita hamarreko hamarkadatik aurrera nahikoa sakon eztabaidatu da ea datiboa egiturazko kasua ala postposizioa den. Eztabaida horretara ekarri zituen Albizuk (2001) izen ondoko datibo sintagmak. ${ }^{3}$ Izen ondoko datibo sintagmez ari garenean, gure lanari izenburua eman dion adibidea bezalakoxeak ditugu gogoan:

\section{(1) Marinelei abisua (EZ Eliç 26)}

Adibide honetan, datibo sintagma bat dugu batetik -marinelei- eta absolutibo sintagma bestetik -abisua-, eta ezkerretara ageri den datibo sintagma hori, absolutibo sintagmaren modifikatzailea da. Izen ondoko datibo sintagma deituko diegu halakoei, goian dagoeneko esan dugun bezala. Hauxe da adibideari dagokion egitura erraztua: ${ }^{4}$

3. Izen ondoko deitura darabilgu ingelesezko adnominal euskaratzeko. Izen ondoko datibo sintagma hauen aipamena egin denean, datibo izenlagunak deitura ere eman zaie (Albizu 2001), euskal gramatikan erabili izan diren izenlagun eta adizlagun esapideen ildotik. Guk izen ondoko hobetsi dugu hemen neutroagoa eta orokorragoa delakoan. Zabalak (1999) berrikusketa kritiko interesgarria egin du, euskalaritzan erabili diren izenondo, izenlagun eta adjektibo hitzen inguruan.

4. DATS laburdura darabilgu analisietan datibo sintagmez ari garenean, eta IS, besterik gabe, ergatibo eta absolutibo sintagmen aipamena egiterakoan. Ez du horrek esan nahi datibo sintagma IStzat hartzen ez dugunik. Besterik gabe, IS hori datibo kasuduna dela azpimarratzearren egiten dugu. 
(2) [[Marinelei $]_{\text {DATS }}$ [abisua $\left.]_{\text {IS }}\right]_{\text {IS }}$

Egitura honetan, abisua IS biltzen duen beste IS konplexuago bat dugu, marinelei modifikatzailea ere biltzen duena.

Goiko adibidea testigantza klasikoetatik jaso dugun arren, halako agerraldiak ere badira gaur egungo euskaran. Adibidez, Beñat Oihartzabalen omenez argitaratu berri den liburu batek (a) du izenburua; (b) zekarren, aldiz, omenaldi-liburuaren aurkezpen ekitaldiko gonbidapenak:

(3) a. Beñat Oihartzabali gorazarre

b. Gorazarre Beñat Oihartzabali

Ikusten denez, datibo sintagma batzuetan eskumatara (a) lerratzen da eta beste batzuetan ezkerretara (b). Hori bera gertatzen da klasikoetan:

(4) a. Iaincoari othoiça (EZ Man II 61)

b. Othoitçac Semeari (EZ Man I 36)

Hitz egingo dugu geroxeago (1.3) hitz hurrenkeraz berriro, zenbait ikertzailerentzat -Makazagarentzat (1999), adibidez-, datuen analisian garrantzia duen auzia dirudi-eta. Momentuz esan dezagun, adibide hauetan, gure ustez, behintzat, egitura bat bera dugula, goian dagoeneko (2) adierazi duguna.

Izen ondoko datibo sintagma hauek bereziak dira, gutxienez, bi arrazoirengatik: a) ez dira adjektiboak, izenari laguntzen dioten arren eta adjektiboak bezalaxe eskumatara lerraturik ager daitezkeen arren; b) ezkerretara lerratzen diren kasuetan, ez dute ez -ko lotura hizkirik ez -(r)en kasu hizkirik erakusten, izenaren ezkerretara azaltzen diren sintagmen kasuan, euskalaritzan izenlagun deitu izan diren horietan, espero litekeen bezala.

Gainerakoan, izen ondoko datibo sintagma hauek behar den bezala interpreta daitezen, kontuan hartu beharra dago izenburuetan ageri direla nagusiki, nahiz eta inoiz edo behin perpaus oso batean txertaturik ere aurki daitezkeen. ${ }^{5}$

(5) a. Huna zer izan ziren haren azken hitzak bere semeeri: "Mutikoak, mutikoak, aski baduzue zeruari beha egonik!" (Larz Idazl V, 51)

b. Ez zen baitezpadako kantua: ${ }^{6}$ bainan zen haren otoitza, haren azken agurra bere lagunari, haren ondorat iragan artio (Mattin 133)

c. Gaur denak ziren bibak eta gorak kapitainari, Caballeriari eta haiez erditu zen amari (Manu 416)

5. Ikus (1.3) atala euskara teknikorako.

6. Josu Landak ohartarazi gaituenez, jatorrizko adibideak kantua dakar, eta ez Euskaltzaindiak (1985: 346), ezta bere ondotik Albizuk (2001: 65), okerretara jaso duten kontua. 
Albizuk berak dakartza (b,c) adibideak: (b) adibidea Euskaltzaindiari (1985: 346) zor zaio eta (c) Agirreri (1991). (a) adibidea, azkenik, Josu Landak jaso du guretzat, Corsintax arakatzaile sintaktikoaz egindako bilaketari esker.

Patxi Goenagak (buruz buru) adierazi digunez, ${ }^{7}$ azken hiru adibide hauek erakusten dutena ez da bakarrik izen ondoko datibo sintagmak perpaus oso batean txertaturik ere ager daitezkeela -eta ez nahitaez izenburuetan-, beste zerbait baino. Bere ustez, hemen egitura berezi bat dago: izan aditza ageri da lehenik, eta bere eskumatara, IS bera eta izen ondoko datibo sintagma ondoren, predikatu konplexua osatuz. Hala da, dudarik gabe, hiru adibideei dagokienez, eta oso litekeena da hala izatea beste agerraldi batzuetan ere, baina datu gehiago behar dugu egiturak ezinbestean halakoa izan behar ote duen jakiteko. Momentuz, guk geuk behintzat, ez dugu antzeko beste alerik aurkitu ez euskalarien lanetan aipaturik, ez, oro har, euskal testuetan, eta ezin dugu, beraz, Goenagaren intuizioa zuzena den ala ez erakutsi. Aldiz, izenburuen eremuan sarriago aurki daitezke (1) bezalako egiturak, eta gaia erabili denean, izenburuetan, behintzat, onargarriak direla esan izan da -de Rijk (1998: 378), ${ }^{8}$ Euskaltzaindia (1985: 346) $)^{9}$ edo Albizu (2001: 63; 2009: 13), adibidez-. Horrek pentsarazten digu izen ondoko datibo sintagma hauek berezko tokia dutela izenburuen sintaxian. Horregatik, gerokoaren zain egon gabe, izenburuak dira lan honetako aztergai nagusi eta bakarra.

\subsection{Izen ondoko postposizio sintagmak eta -ko lotura hizkia}

Izen ondoko datibo sintagmen jokabide sintaktikoa ulertzeko, izen ondoko postposizio sintagmak dira giltzarri, hauexek, esaterako:

(6) a. Jacob-en jaisquera Egipto-ra (Lard 61)

b. Saul-gandic David-en iguesa (Lard 168)

Adibide hauetan, jaisquera eta iguesa ISen ondokoak ez dira datibo sintagmak, postposizio sintagmak baino -Egiptora adlatiboaz eta Saul-gandic ablatiboaz markatutakoak-. Halako postposizio sintagmak ikusirik, arrazoizkoa dirudi pentsatzeak datiboek postposizioek bezalatsu jokatzen dutela, honi dagokionez, bederen, batzuk zein besteak izen ondoko modifikatzaileak izan baitaitezke, beste inongo loturarik gabe.

Lehenago izen ondoko datibo sintagmez esan dugun bezala, postposizio sintagma hauek izenaren modifikatzaileak dira, eta batzuetan (a), adjektiboen kokapen bera erakusten dute. Bestalde, ezkerretara lerratzen direnean (b) ere, postposizio sintagma hutsa dugu eta ez dago ez -ko lotura hizkiaren ez -(r)en genitiboaren arrastorik. Ezaugarri bi horiek datibo sintagmen eta postposizio sintagmen arteko antzekotasuna azpimarratzera eraman gaitzakete. Itxuraz, beraz, antzekoak dira izen ondoko postposizio sintagmen (7) egitura ${ }^{10}$, eta lehenago izen

7. Eskerrik asko Patxi Goenagari ohar honengatik, geroagoko lanetarako gogoan izango duguna.

8. De Rijkek, berez, ondoren (1.2) ikusiko ditugun postposizio sintagmak ditu hizpide, izenburuak salbuespen direla dioenean.

9. Euskaltzaindiak (1985: 346) berez dioena da perpaus hauek zuzenegiak ez diruditela, baina izenburuetan onargarriagoak direla.

10. Postposizio sintagma biltzen duen egitura erraztua baino ez dugu jasotzen, genitibo kasuko sintagma isilduz. 
ondoko datibo sintagmei egotzi dieguna (2).

(7) $\left.[\text { [Saul-gandic }]_{\mathrm{PS}}[\text { iguesa }]_{\mathrm{IS}}\right]_{\mathrm{IS}}$

Nolanahi ere, bada, gutxienez, ezberdintasun aipagarri bat: ezkerretara lerratzen diren postposizio sintagmek -ko lotura hizkia erakuts dezakete aukeran.

(8) a. Jacoben Egiptorako jaiskera

b. Daviden Saulengandiko ihesa

Adibide hauek, (6)koekin alderatuz gero ikus daitekeenez, postposizio sintagma hutsen ordez -Egipto-ra, Saul-gandik-, -ko lotura hizkia duten sintagmak dira -halako adibideetan, -ko lotura hizki horrek postposizio sintagma osoa hartzen du osagarri gisa (9)-.

(9) [ [ [Saul-gandik $\left.\left.\left.]_{\mathrm{PS}}-\mathrm{ko}\right]_{\text {[iguesa }}\right]_{\mathrm{IS}}\right]_{\mathrm{IS}}$

Postposizio sintagma hutseko adibideak (6) gramatikalak dira, gure ustez -guk dakigula, -ko lotura hizkidun adibideen gramatikaltasunaz (8) ez dago zalantzarik-. Dena den, kontuan izan izenburuen sintaxira mugatu dugula gure lana hasieratik, eta postposizio sintagma hutseko adibideak gramatikalak direla diogunean, printzipioz izenburuez ari garela -lehenago (1.1), izen ondoko datibo sintagma gisa aipatutakoen antzera-. Hortaz, ez ditugu ahaztu de Rijkek $(1988,1993)$ aspaldi -ko hizkiaz irakatsitakoak, alegia, ingelesez ez bezala, euskaraz, -ko lotura hizkiaren beharra dutela postposizio sintagmek, izen sintagma baten barruan agertu ahal izateko. Orobat, gogoan dugu izenburuetatik aparte, (7) egitura ez-gramatikala dela de Rijkentzat. Bere adibideak dira ondokoak (de Rijk 1998: 378):

(10) a. * Loturak etsaiarekin

b. *Mahaiak bezeroentzat

c. *Ogia zerutik

d. *Bidea Gasteiztik Bilbora

e. *Itzulpenak gaztelaniatik ingelesera

Alderantzizko hurrenkera dutenak ere ez-gramatikaltzat hartzen ditu:

(11) a. *Etsaiarekin loturak

b. *Bezeroentzat mahaiak

c. * Zerutik ogia

d. *Gasteiztik Bilbora bidea

e. *Gaztelaniatik ingelesera Itzulpenak

Bat gatoz, bada, uste honekin, beti ere izenburuak alde batera uzten baditugu. Nolanahi ere den, de Rijkek berak dio (1998: 378), (11) adibideak gramatikaltzat har litezkeela izenburuetan, eta guk bezala, Lardizabalen Testamentu zarreco eta berrico condairatik (1855) jasotzen ditu gure aztergai diren izenburuak. Beraz, arauaren salbuespena da guk mintzagai duguna eta hizkuntza osora orokortu ezin daitekeena. Gogoan izan, honi dagokionez, egileak, euskara 
bezalakoxe beste hizkuntza batzuk ere aipatzen dituela, alegia, ketxuera, japoniera, turkiera eta hungariera aurre-modernoa: hizkuntza hauetan guztietan, postposizio sintagma hutsak ezin daitezke IS baten modifikatzaileak izan, ez bada izenburuen eta antzekoen eremuan. Ondorioz, hizkuntza hauetan, murriztapenen bat egon badago, ingelesez, gaztelaniaz edo frantsesez, esaterako, ez dagoena.

-Ko lotura hizkiaren azterketak oso urrunera eramango gintuzke, eta gure asmoa, ez da izatez maisuaren pausuei jarraituz, hura aztertzea, ez bada izen ondoko sintagmekin zerikusia izan dezakeen heinean. Bada, nahiz eta goian esan dugun lotura hizki hori aukeran postposizio sintagmei gaineratu dakiekeela, ez dirudi hori bera esan daitekeenik izen ondoko datibo sintagmez ari garenean.

(12) a. *Marineleiko abisua

b. *Beñat Oihartzabaliko gorazarre

De Rijk-ek, aipatu ditugun lan bietan azaldu zuen hori. Orobat, Elordietak (2001: 64-65) hori bera gogorarazi digu geroago, datibo sintagmak ISak direla, ez postposizio sintagmak, aldarrikatzeko. Gure ustez, datibo sintagmak IS ala postposizio sintagma diren erabakitzeko, ezin dugu bakarrik kontuan hartu datibo sintagmak postposizio sintagmak bezalaxe izen ondokoak izan ote daitezkeen ala ez; horretaz gain, ikusi beharra dago batzuek eta besteek zein harreman duten -ko lotura hizkiarekin zein -(r)en kasu markarekin, biek berebiziko garrantzia dutelako ISen modifikatzaileak sortzerakoan. Berehala (2 atala), helduko diogu - ( $r$ ) en kasu markaren azterketari, honetan ere, diferentzia esanguratsuak daude-eta datibo eta postposizio sintagmen artean.

1.3 Datibo sintagmen zein postposizio sintagmen hurrenkeraz; balizko beste analisi bat

Lan honen hasieratik aipatu dugu izen ondoko sintagmak ISren eskuma zein ezkerretara ager daitezkeela, eta hala agertzen direla egile klasikoetan eta gaur egungo prentsa izenburuetan. Dena den, hizkuntzalarietako batzuk, Euskaltzaindiak (1985: 346) edo Albizuk (2009) ${ }^{11}$, esate batera, zeharbidez edo esplizituki, izen ondoko sintagma hauek eskumatara lerratzen direla esan edo iradoki dute, iritzi guztiak bat ez datozen arren. Esaterako, de Rijkek (1998: 378), (11) adibideak izenburuetan zilegi izan daitezkeela dio, hau da, bere ustez, gramatikalak izan litezke modifikatzailea ezkerretara erakusten dutenak; eskumatara lerratzen diren sintagmez -(10) sortakoez-, aldiz, ez du argibiderik ematen. Inplizituki, beraz, eskumatara lerratzen diren postposizio sintagmak ez-gramatikaltzat hartzen dituela dirudi.

Esplizituagoak dira beste hizkuntzalari batzuk, eta itxuraz kontrako iritzikoak -darabilten arrazoibidea diferentea izan arren-. Adibidez, euskara teknikoko testuez ari dela, Makazagak (1999: 46) dio izen ondoko sintagmak ezkerretara lerratzen diren adibide hauek guztiak ezgramatikalak direla:

11. Albizuk adnominales dativos a la derecha izenburupean aztertzen du egitura hau. 
(13) a. *Penizilinari erresistentzia

b. *Salizitatoei alergia

c. *Antibiotikoekin tratamendua

d. *Gaindosiagatik heriotza

e. *Dosi altuetan C bitamina

Dena den, orrialde bereko (16) oin-oharrean dio (a) bezalakoek badutela literatur tradizioa eta zerurabide bezalako egitura ihartuak kontuan hartu behar direla. Guk, ikusiko dugunez, literatur tradiziora jo dugu, hain zuzen, gramatikalak direla erakusteko. Gainerakoan, ez genuke esango zerurabide bezalakoak ihartuak direnik, azken batean, etxera bidean, unibertsitatera bidean, eta abar, lasai asko esan daitezke-eta. Dena den, bide hitza da hemen gakoa, itxuraz, berak ematen digulako izen ondoko postposizio sintagma erabiltzeko aukera.

Ez dirudi, baina, izeondoko sintagmak ezkerretara agertze hutsa denik, Makazagaren ustez, goiko adibideak ez-gramatikal bihurtzen dituena, ez bada, izen ondoko sintagmak eurak agertzea. ${ }^{12}$ Azken adibideak ez-gramatikalak direlako ustea indartzeko, perpausean txertatuz gero, are ez-gramatikalagoak direla dio Makazagak.

(14) a. *Penizilinari erresistentzia garatu da

b. *Salizitatoei alergiari aurre egin behar zaio ${ }^{13}$

c. *Antibiotikoekin tratamendua agintzen dute medikuek

d. *Gaindosiagatik heriotza

e. *Dosi altuetan C bitamina

Dena den, sintagma guztiak ez dira berdinak, batzuk eskumatara lerraturik onartzen baititu:

(15) a. *Gaindosiagatik heriotza bat gertatu da

b. Heriotza bat gertatu da gaindosiagatik

c. ${ }^{*}$ Dosi altuetan $\mathrm{C}$ bitamina eman da

d. C bitamina dosi altuetan eman da

e. *Dosi altuetan $\mathrm{C}$ bitamina

Eta bide honetatik, ondokoak ere gramatikaltzat jotzera heltzen da:

(16) a. Alergia salizitatoei

b. Tratamendua antibiotikoekin

c. Heriotza gaindosiagatik

12. Nolanahi ere, Makazagaren testua interpretatu beharra dago. Hitzez hitz dioena hauxe da: "jakina baita ez direla onargarriak adizlagunak izen sintagmaren barnean.” (Makazaga, 1999: 46). Izatekotan, adizlagunak-en ordez izenlagunak beharko luke hemen, gure iritziz. Zerurabide bezalakoak badira (12) sortako adibideak, orduan ezin daiteke esan zerura adizlaguna denik, bide izena modifikatzen dute-eta. Egilea, beraz, izen ondoko sintagmez ari da, gure iritziz.

13. Salizitatoei alergiari aurre egin behar da esaldia dakar berez Makazagak datibo komunztadurarik gabe. Salizitatoei sintagmak, jakina, ez du komunztadurarik eragiten. Alergiak, berriz, bai, euskara batuan, behintzat. 
Alabaina, irakurleak kontuan hartu behar du Makazagak (15)eko adibideak gramatikalak direla dioenean, ez dituela datibo sintagma edo postposizio sintagma hauek izen ondokotzat hartzen, aditz ondokotzat baino -bestela esanda, ez du uste izena modifikatzen dutenik, aditza baino-. ${ }^{14}$ Hortaz, ziur aski berak gogoan dituen egiturak ez dira (2) edo (7) -ondoko (a) eta (b) egiturak, hurrenez hurren-:

(17) a. [[Erresistentzia $\left.]_{\text {IS }}[\text { penizilinari }]_{\text {DaTS }}\right]_{\text {IS }}$

b. [[Tratamendua $]_{\mathrm{IS}}$ [antibiotikoekin $\left.]_{\mathrm{PS}}\right]_{\mathrm{IS}}$

Horien ordez, beharbada, IS konplexu berean sartzen ez diren sintagma beregainak izango ditu gogoan: ${ }^{15}$

(18) a. [Erresistentzia $\left.]_{\mathrm{IS}}[\text { [penizilinari }]_{\left.\mathrm{DATS}_{\mathrm{S}}\right]}\right]_{\mathrm{AS}}$

b. $\left.[\text { Tratamendua }]_{\mathrm{IS}}\left[[\text { antibiotikoekin }]_{\mathrm{PS}}\right]\right]_{\mathrm{AS}}$

Jakina, gu ez gara halako egiturez ari, ez, behintzat, orain arteko sintagmez hitz egiten ari garela. Dena den, batzuetan itxura bereko sintagmak ez dira izen ondokoak, eta Makazagaren testua behar bezala interpretatu badugu, behintzat, bestelako egiturak dira hauek. Adibidez, ondoko perpausetan, postposizio sintagmak (a,b) eta datibo sintagmak (c,d) ez dira beste ISen modifikatzaileak, sintagma beregainak baino:

(19) a. Suizidioak epaitegira (Berria, 2010-04-10)

b. Azken berriak kosmosetik (Berria, 2010-04-14)

c. Aukera bat aldaketari (Berria, 2010-04-01)

Aldiz, ondoko hauek, gure iritziz, izen ondokoak dira:

(20) a. Basamortuei begirada (Berria, 2010-03-14)

b. Oposizioari erantzuna (Berria, 2010-03-18)

c. Sexualitateari deia (Berria, 2010-04-04)

d. Miranderi mira (Berria, 2010-03-21)

e. Rubalcabaren deia Urkulluri (Berria, 2010-03-20)

f. Omenaldia artzaintzari (Berria, 2010-04-08)

Izen ondoko postposizio sintagmadunak ere bai:

(21) a. Txotxongiloen etxe magiko eta ederrera bisita (Berria, 2010-03-13)

b. Telebisten hilerrira bisita (Berria, 2010-05-15)

14. Berriro ere bere hitzak interpretatzen ari gara: "hauetako batzuk ordea onak dira hitz-hurrenkera aldatu eta adizlaguna izena laguntzeko saiorik egin gabe aditza laguntzeko moduko gune batean kokatzen dugunean." (Makazaga, 1999: 46, 16 oin-oharra).

15. Ikusi beharko da gero ea IS beregain horiek aditz sintagma (AS) berean edo beste osagai konplexu batean biltzen diren. Honek ez du orain guretzat garrantzirik. 
Nolanahi ere, batzuetan, bereziki ISren eskumatara lerratzen diren datibo sintagmekin zalantza sortzen da, ea izen ondoko sintagma bat ote dugun ala ez. Adibidez, goiko (f) adibideak, (17a) edo (18a) egituretatik edozein izan lezake. Guk izen ondoko sintagmatzat hartuko genuke, (17a) egitura hobetsiz, baina irakurleari erakutsi diogunez, ez gatoz denok bat honetan: Makazagak (18a) egotziko lioke ziur aski.

Azkenik, hitz hurrenkeraren gaira itzuliz, ikusten denez, izen ondokoak diren sintagmak eskumatara zein ezkerretara ager daitezke bai oraingo testuetan bai klasikoetan ere, goian dagoeneko esan dugun bezala:

(22) a. Jacob-en jaisquera Egipto-ra (Lard 61)

b. Jerusalen-era David-en itzulera (Lard 202)

c. Othoitçac Semeari (EZ Man I 36)

d. Iaincoari othoiça (EZ Man II 61)

Zalantzak ditugu, beraz, Euskaltzaindiak (1985: 346) dioenean eskumatara lerratzen diren izen ondoko datibo sintagmak onargarriagoak direla ezkerretara lerratzen direnak baino. Itxura batean, ASren periferiakoak diren sintagmak, ISren eskumatara agertzea espero genezake. Baldin eta Euskaltzaindiak Makazagak bezala, ASren barruko sintagmatzat jotzen baditu, orduan ulertzekoa da hitz hurrenkeraz dioena. Aldiz, izen ondoko ISren modifikatzaileak direla uste badu, orduan aitortu beharko du bietara ageri zaizkigula. Xehetasunez aztertu beharreko gaia da hurrenkerarena, gauzak gehiegi sinplifikatu nahi ez baditugu, bederen.

\subsection{Izen ondoko datibo sintagmak ezinezkoak direnean}

Orain arte ikusi ditugun datibo sintagma guztiak nola edo hala izen ondokoak izan daitezke. Baieztapen honek, alabaina, oso muga garbia du: esperimentatzaileek eta jabe edo interes datiboek sortzen dituzten sintagmak ezin dira inola ere izen ondokoak izan. Bestela esanda, goi-datiboak, behe-datiboak ez bezala, ezinezkoak dira egitura honetan.

(23) a. *Begitazioa/begitanduera umeei / *Umeei begitazioa/begitanduera ${ }^{16}$

b. *Irudipena umeei / *Umeei irudipena

c. *Gogorapena umeei /*Umeei gogorapena

d. *Ahanztura/ahanzpena umeei /*Umeei ahanztura/ahanzpena

Adibide guztiak ez-gramatikalak dira. Baita jabe eta interes datiboak jasotzen dituzten ondoko adibide hauek ere:

(24) a. *Aita eta amaren hilketa Jenebiebari /*Jenebiebari aita eta amaren hilketa

b. *Denei gogoaren ilunketa / *Gogoaren ilunketa denei

c. * Itsuari begien argiketa / * Begien argiketa itsuari

16. Bi hitz-hurrenkera aipatzen ditugun arren, eskumatara lerratutako goi-datiborik ez genuke inoiz espero izango, ezta egitura hau goi-datiboekin zilegi balitz ere. Albizuk (2009), aldiz, eskumatara baino ez ditu lerratzen bere adibideetan. 
Halaxe adierazi dugu lehenago ere (Fernández 2007). Albizuk (2009), bere aldetik, esperimentatzaileen eta jabe eta interes datiboen arteko ñabardurak aipatzen ditu gramatikaltasun juzkuetan: esperimentatzailedun egiturak guztiz ez-gramatikalak direla dio, eta jabe edo interes datibodunak edo ez-gramatikalak edo zalantzatakoak. Gu ez gatoz bat berarekin ez puntu honetan ez ondokoetan. Lehenik eta behin, falta (izan) esperimentatzaileen artean kokatzen du, guk interes datibotzat joko genukeen arren -*asti falta Joni lana bukatzeko da bere adibidea. Horrek ez du, printzipioz, inongo eragozpenik sortzen, azken batean, ez baitago, gure ustez, Albizuren ustez ez bezala, esperimentatzaileen eta jabe edo interes datiboen artean jokabide sintaktiko bereziturik. Bigarrenik, jabe eta interes datiboetan aipatzen dituen adibideak hauexek dira:

(25) a. *??Itasontziaren hondoratzea kapitainari

b. */??Bitxien galera/galtzea Mireni

Adibide hauetan, hondoratzea eta galtzea nominalizazioak ageri zaizkigu. Printzipioz, nominalizazioa agertuz gero, ez dugu ikusten arrazoirik datiboa ezin agertzeko. Besterik da, jakina, galera izena. Hirugarrenik, ez dugu uste esan daitekeenik ez oro har, ez Albizuk dakartzan adibideetako datibo zehatz horietan, jabe eta interes datiboak postposizioak direnik -ikus Fernández eta Ortiz de Urbina (2010)-.

Ikusten denez, zenbait diferentziek bereizten gaituzte Albizuren ekarpenetik. Diferentziak alde batera, irakurleari erakutsi nahi dioguna da besterik gabe, datiboetatik batzuk halako egituretan ezinezkoak direla. Hiztunen juzkuak alde batera, guk dakigula behintzat, ez klasikoetan, ez gaur egungo prosan ez dago euren erakusgarri bat bera ere.

\section{Izen ondoko sintagmak eta -(r)en genitiboaz}

Ikus dezagun orain zein den $-(r)$ en genitiboaren zeregina izen ondoko sintagmak sortzerakoan. Has gaitezen ikusten zein diren aukera hori besterik ez duten ISekin.

\section{1 -(r)en genitiboa aukera bakarra denean (I): ergatibo eta absolutibo sintagmez}

Ergatibo eta absolutibo sintagmak ezin daitezke izen ondoko modifikatzaileak izan, ez bada -(r)en genitiboaren bidez. Esate batera, beheko (b) adibidea ez-gramatikala da, ukamena ISak ezin baitu Pedrok ergatibo sintagma, izen ondoko modifikatzaile gisa hartu. Ergatiboaren ordez, -(r)en genitiboa eman beharra dago, sintagma gramatikala erdiesteko (a).

(26) a. Pedro-ren ucamena (Lard 447)

b. *Pedrok ukamena

Gogoratu zein den lanaren hasieran eman dugun egitura, adibide hauek ere behar bezala uler daitezen. (b) adibideari dagokion egituran, Pedrok ergatibo sintagma izen ondoko modifikatzailea da eta, beraz, IS osoaren barruan dago:

(27) a. [[Pedroren $\left.]_{\mathrm{IS}}[\text { ukamena }]_{\mathrm{IS}}\right]_{\mathrm{IS}}$ b. $\left.{ }^{*}\left[{ }_{\text {Pedrok }}\right]_{\mathrm{IS}}[\text { [ukamena }]_{\mathrm{IS}}\right]_{\mathrm{IS}}$

Geroago ikusiko dugunez, badira, itxuraz oso antzekoak izanik ere, hau ez bezalako egitura 
ezkutatzen duten adibideak, gramatikalak direnak -(3) atala-.

Ergatibo sintagmez esandakoa absolutibo sintagmez ere esan daiteke: ezin zaizkio zuzenzuzenean beste IS bati lotu (b,d), eta -(r)en genitiboa behar dute izen ondokoak izateko $(\mathrm{a}, \mathrm{c})$ :

(28) a. Jerusalen-era David-en itzulera (Lard 202)

b. *Jerusalen-era David itzulera

c. Bi gaizquindunen sendamena (Lard 388)

d. *Bi gaizkindunak sendamena

(b) adibidean, absolutibo sintagma subjektua da eta (d) adibidean, osagarria. Bi agerraldiak (b,d) ez-gramatikalak dira.

\section{2 -(r)en genitiboa aukera bakarra denean (I): goi-datiboez}

Ergatibo eta absolutibo sintagmen jokabide berbera erakusten dute goi-datiboek, edo nahiago bada, esperimentatzaileek eta jabe edo interes datiboek: izen ondokoak bihurtu nahi izanez gero, orduan -(r)en genitibo kasuaz markatzea da duten aukera bakarra.

(29) a. *Begitazioa/begitanduera umeei / *Umeei begitazioa/begitanduera

b. Umeen begitazioa/begitanduera

c. * Irudipena umeei / *Umeei irudipena

d. Umeen irudipena

e. Gogorapena umeei / *Umeei gogorapena

f. Umeen gogorapena

g. *Ahanztura/ahanzpena umeei / *Umeei ahanztura/ahanzpena

h. Umeen ahanztura/ahanzpena

Lehenago irakurleari eman dizkiogun goi-datibodunen adibideetatik, esperimentatzaileak dira hauek $(a, c, e, g)$, euren ordezko genitibodunekin batera (b,d,f,h). Ikusten denez, goi-datibo horiek ergatibo eta absolutiboak bezalakoxeak dira: ezin daitezke zuzenean izen ondoko modifikatzaileak izan, eta baldin eta izena lagundu nahi badute, orduan, behar-beharrezkoa dute -(r)en kasuaz ordezkatzea.

Jabe eta interes datiboen kasuan, are naturalagoa da genitiboaren bitartez ematea. Lehenik eta behin, jabetza berez genitiboaren bitartez adierazten dugulako, eta jabe datiboa agertuz gero, igoeraren ondorioz gertatzea espero dugulako. Horregatik, (a) gramatikala da eta (b), berriz, ez. Interes datiboetatik hurbilago dauden (d,f) adibideen ordezko genitibodunetan, galdu egiten da interes kutsua.

(30) a. Jenebiebaren aita eta amaren hilketa

b. *Aita eta amaren hilketa Jenebiebari

c. Denen gogoaren ilunketa

d. *Gogoaren ilunketa denei

e. Itsuaren begien argiketa

f. *Begien argiketa itsuari 
Oso jokabide bateratsua erakusten dute jabe eta interes datiboek hemen, bata bestetik ezin bereizteraino.

Hortaz, datiboak egiturazko kasuen edo postposizioen antzera jokatzen ote duen erabaki behar bada, ezin daiteke bakarrik esan postposizioen gisara jokatzen duela izen ondoko modifikatzaileei dagokienez, hori behe-datiboei baino ezin baitzaie egotzi. Orobat, esan beharko da -(r)en genitiboaz ere ordezka daitezkeela datibo sintagmak, ergatibo eta absolutibo sintagmak bezalaxe. Jakina, postposizio sintagmak ezin daitezke-(r)en genitiboaz markatu, eta bere ordez, -ko lotura atzizkiaz baliatu behar dute -gogoratu, gainerakoan, datibo sintagmak, postposizioak ez bezala, ezin daitezkeela - ko lotura atzizkiaz baliatu, (1.2) atalean erakutsi dugun bezala-.

\section{$2.3-(r) e n$ genitiboa aukeretatik bat izan daitekeenean: behe-datiboez}

Orain artean erakutsi dugunez, ez ergatibo ez absolutibo ez goi-datibo sintagmak ezin daitezke inoiz ere izen ondoko modifikatzaile gisa agertu, eta beharrezkoa dute - $(r) e n$ genitiboa izen ondoko bihurtzeko. Behe-datiboez ari garela, $-(r)$ en genitiboa, izen ondoko datiboaren ordez aurki daiteke inoiz. Adibidez, Jules Verneren nobela ederrenetako batek, ondoko izenburua du euskaraz argitaratutako itzulpen batean:

(31) Munduari itzulia 80 egunetan

Alabaina, ez da euskaraz egin den itzulpen bakarra. Bada beste bat, izenburua bestela itzulita dakarrena:

(32) Munduaren itzulia 80 egunetan

Ikusten denez, datiboaz zein genitiboaz markaturik ageri da izen ondoko sintagma.

Euskaltzaindiak ere (1985: 346) aipatzen du genitiboaren aukera, zuzenegiak iruditzen ez zaizkion izen ondoko datibo sintagmen aldean. Anbiguetatea ere sortzen dela dio, eta halaxe da. Esate baterako:

(33) a. Oihartzabali gorazarrea

b. Oihartzabalen gorazarrea

c. Omenaldia artzaintzari

d. Artzaintzaren omenaldia

(b) eta (d) adibideetan, genitiboak ordezkatzen dituen kasuak bi izan daitezke: ergatiboa zein datiboa. Jo dezagun Oihartzabal dela gorazarrea egiten duena, Lafitteri adibidez, orduan genitiboak ergatiboa ordezkatzen du; aldiz, Oihartzabal bada gorazarrea jasotzen duena -helburua denean, alegia-, orduan datiboa da genitiboak ordezkatzen duena.

Beraz, sintagma genitiboduna sintaktikoki anbiguoa izan daiteke, goikoak bezalako kasuetan, baina horrek ez du esan nahi datiboa, ergatiboa eta absolutiboa bezalaxe genitiboaz ordezka ezin daitekeenik. Diferentzia da, jakina, ergatiboak eta absolutiboak goi-datiboen antzera, genitiboa beste biderik ez dutela izen ondokoak sortzeko, eta behe-datiboak, berriz, kasu batzuetan, behintzat, bi aukerak dituela, bata datibo gisa agertzea eta bestea genitibo kasuaz markatzea. Nolanahi ere den, ñabardura bat gaineratu behar zaio honi, batzuetan 
datibo sintagma ez baita horren erraz eskuratzen genitibo sintagma batetik, esate baterako, goian dagoeneko aipatu ditugun $(\mathrm{a}, \mathrm{c})$ adibideen ordezko genitibodunetatik (b,d):

(34) a. Oposizioari erantzuna

b. Oposizioaren erantzuna

c. Sexualitateari deia

d. Sexualitatearen deia

Zehaztu beharko da, beraz, zein testuingurutan interpreta daitekeen datiboa dugula eta zein testuingurutan ez.

\section{Izen ondoko datibo eta postposizio sintagmak euskal klasikoetan}

Izen ondoko datibo eta postposizio sintagmen agerpena, guk dakigula, ez da aztertu izan klasikoen eremuan, eta atal honetan, hain zuzen, eremu honi begiratu eta, gure ustez, esanguratsuak diren bi idazle aztertuko ditugu: Lardizabal batetik -(3.1) atala- eta Etxeberri Ziburukoa bestetik -(2.2) atala-. Bien lanetan aurki daitezke aztergai ditugun egiturak. Ostean, izenburuak ematen dituzten beste idazle batzuen estrategiak oso aztergai interesgarriak izan daitezke, Leizarragaren elipsia adibidez, baina, guk dakigula, behintzat, ez darabilte orain mintzagai dugun egitura hau. Geroago -(3.3) atala-, aipatuko dugu labur.

\subsection{Francisco Ignacio Lardizabal eta izen ondoko sintagmak}

Testamentu zarreco eta berrico condaira (1855) irakurtzerakoan, berehala aurkituko ditu irakurleak izen ondoko datibo zein postposizio sintagmak izenburuetan. Sarri askotan, genitibo sintagma ere ageri da tartekaturik. Ondoko sortan ikus daitezke adibideak - (a,b) eta (c,d)-. Hitz hurrenkerari dagokionez, bietara lerratzen dira izen ondoko sintagmak, eskumatara $(a, c)$ zein ezkerretara $(b, d)$ :

(35) a. Jacob-en jaisquera Egipto-ra (Lard 61)

b. Jerusalen-era David-en itzulera (Lard 202)

c. Jesus-en aguerquera Apostoluai (Lard 472)

d. Moisesi Jaincoaren aguerquera (Lard 66)

Genitibo sintagma, bestalde, izenaren ondokoa izan ohi da -(a,b) adibideak-salbuespenen batekin:

(36) Jonatas-en Toleimada-ra joanera (Lard 351)

Adibide guztietatik, datibodunak dira, postposiziodunen aldean gutxien testu osoan zehar. Goian aipatu ditugun adibideez gain (c,d), aguerquera izena bera duten antzeko beste lau agerraldi ditugu testu berean, esate baterako ondoko (a) adibidea. Bestelakoa da (b). Oro har, beraz, zazpi agerraldi ditu izen ondoko datibo sintagmadun egiturak lan honetan.

(37) a. Jesus-en aguerquera Maria guciz Santari (Lard 476)

b. Mateo-ri Jesus-en deya (Lard 390) 
Postposiziodunak, berriz, askotxo dira, eta aldakorragoak -oinarrian beti egitura bat bera izan arren, alegia, izen ondoko postposizio sintagma-. Egitura honetan ageri diren izenak diren bezainbatean, gehienak mugimenduzko aditzetatik eratorritako izenak dira, eta, hortaz, argumentu bakarrekoak -joanera, jaisquera, irteera, iguesa, ezcutaquera-; argumentu biko izenak ere badira -ipiñera, eramanera; eta badira, azkenik, bietara interpreta daitezkeenak -itzulera-. ${ }^{17}$ Postposizioei dagokienez, goian $(35 \mathrm{a}, \mathrm{b})$ adibideetan erakutsi dugun adlatiboaz gain, ablatibo bizidun zein bizigabea (a,b), ablatibo eta adlatiboa biak batera (c), eta azkenik, inesiboa (f) ere ageri dira.

(38) a. Saul-gandic David-en iguesa (Lard 168)

b. Mundutic Elias-en ezcutaquera (Lard 236)

d. Jerusalen-dic Betania-ra Jesus-en joanera (Lard 420)

e. Maria-ren vicitza Nazaret-en (Lard 365) ${ }^{18}$

Bestalde, genitiboak absolutiboa ordezkatzen du Lardizabalen liburuko agerraldi gehienetan. Adibidez, mugimenduzko aditzetatik eratorritako izen guztiekin batera jaso daitezkeen genitiboak $(\mathrm{a}, \mathrm{c})$ absolutiboaren $(\mathrm{b}, \mathrm{c})$ ordezkoak dira. Kasu hauetan guztietan absolutibo sintagma subjektua da, adibidez:

(39) a. Mundutic Elias-en ezcutaquera (Lard 236)

b. *Elias mundutik ezkutakera

c. Jacob-en joanera Haran-era (Lard 35)

d. *Jacob Haranera joanera

Izartxoa gaineratu diegu (b,d) adibideei, absolutibo sintagmarik ezin baitaiteke ageri dagoen dagoenean beste IS bat modifikatzen. Lehenago erakutsi dugun bezala -(2.1) atala-, $(b, c)$ adibide ez-gramatikalen ordain gramatikalak izateko beharrezkoa dugu genitiboa.

Izena aditz iragankor batetik eratorri den kasuetan, genitiboak ordezkatzen duen absolutiboa osagarria da:

(40) a. Cucha santaren itzulera Israel-era (Lard 153)

b. *(Haiek) Kutxa santua Israelera itzulera

c. Jesus-en Getsemani-tic Jerusalen-era eramanera (Lard 445)

d. *(Haiek) Jesus Getsemanitik Jerusalemera eramanera

e. Bi gaizquindunen sendamena (Lard 388)

f. *(Hark) Bi gaizkindunak sendamena

17. Argumentu, bakarreko, biko eta abar diogunean, testuan erakusten den benetako konfigurazioaz ari gara.

18. Postposizioen artean, inesiboak dirudi eskumatara halabeharrez lerratzen direnetakoa. Lardizabalen lanean ez dugu aurkitu Nazaret-en Maria-ren vicitza bezalakorik, eta kasu honetan, besteetan ez bezala, gure intuizioa da datibo sintagma ezkerretara lerratzen bada, orduan -ko erlazio atzizkia behar duela (Mariaren Nazareteko bizitza). Oso litekeena da halakoak izatez izen ondoko modifikatzaileak ez izatea eta lehenago eman dugun egitura alternatiboaren (18) argitara ulertu ahal izatea, Makazagaren ildotik. 
Izartxoa jarri diegu berriro ere, kasu honetan, izenak dituen bi argumentuak, alegia, ergatiboa eta absolutibo sintagmak ezin daitezkeelako ihesa edo deia bezalako ISak zuzenean modifikatzen agertu, ez bada genitiboz ordezkatu eta gero.

Gainerakoan, genitiboak ergatiboa ordezkatzen du ondoko adibideetan:

(41) a. Saul-gandic David-en iguesa (Lard 168)

b. (*)Davidek Saulengandik ihes

c. Mateo-ri Jesus-en deya (Lard 390)

d. (*)Jesusek Mateori deia

e. Iru Erregueen adoracioa (Lard 367)

f. *Hiru Erregeek (Jesus) adoracioa

g. Animaco janariaren gañean Jesus-en itzqueta (Lard 401)

h. *Arimako janariaren gainean Jesusek hizketa

i. Pedro-ren ucamena (Lard 447)

j. *Pedrok ukamena

Jakina, goiko (b,d,f,h,j) adibideen ez-gramatikaltasuna zeharbidez baino ezin dugu erakutsi, ez-gramatikalak direnez, ez baitugu, jakina, testuan agertzea espero. Geroago ikusiko dugunez, badago nahikoa adierazgarria den salbuespen eremua ergatiboari dagokionez -(4) atala-, baina gure ustez, bestelakoa izan behar du bere egiturak. ${ }^{19}$ Dena den, argi dago ez absolutibo ez ergatibo sintagma ezin daitezkeela izen ondoko modifikatzaileak izan aztergai ditugun izenburuetan. Bestalde, ergatiboa agertzen den kasuetan, perpaus oso bat dugu: edo perpaus jokatugabea da, nahiz nominalizazioa (a) nahiz partizipioa (b); edo besterik gabe, perpaus jokatua $(\mathrm{c}, \mathrm{d})$, aditzarekin eta inflexioarekin batera.

(42) a. Jesus-ec Apostoluai oñac garbitcea (Lard 438)

b. Jerusalen Tito-c setiatua (Lard 541)

c. Aingueruác María-ren izaera José-ri aguertcen dio (Lard 366)

d. Jesus-ec itsas-aserretuan Apostolúac gordetzen ditu (Lard 400)

Ikusten denez, ergatiboa ez da behin ere agertzen mintzagai dugun egituran, eta gainerako agerraldietan, ezaguna zaion testuingurua erakusten du.

Amaitzeko, goi-datiborik ez dago Lardizabalen izen ondoko sintagmetan eta hori gure hasierako hipotesia berrestera dator: goi-datibo bat bera ere ez da Lardizabalen testuko izenburuetan, halako egituretan goi-datiboak, besterik gabe, ezinezkoak direlako.

\subsection{Joanes Etxeberri Ziburukoa eta izen ondoko sintagmak}

Gure lanari izenburua ematen dion adibidea, Marinelei Abisua, Etxeberri Ziburukoaren Eliçara erabiltceco liburua (1636) lanetik jasota dago. Liburu honetan badira aipatutako adibide horretaz gain, beste agerraldi batzuk ere, baina, oro har, sarriago aurki daitezke izen

19. Litekeena da hemen ez-gramatikaltzat jotzen ditugun (b,d) adibideak ere gramatikalak izatea, ergatibo sintagma beregaina dela pentsatuko bagenu, hau da, ihes eta deia izenen modifikatzailea ez dena. Horregatik jarri diegu izartxoa parentesi artean. 
ondoko datibo sintagmak bere Manual Devotionezcoan (1627). Hona dakartzagu euretatik batzuk:

(43) a. Othoitçac Semeari (EZ Man I 36)

b. Aingueruei errencurac eta othoitçac (EZ Man I 122)

c. Aingueruen inspirationea egoquiei (EZ Man I 124)

d. Iaincoari agurra (EZ Man II 40)e. Iaincoari othoiça (EZ Man II 61)

f. Itsasturi Iracurtzaileeari. Abisua. (EZ Man II 129)20

g. Promessa Iaincoari (EZ Man II 148)

Egitura hauetako izen nagusia ondoko bat izan ohi da: abisua, agurra, arrenkurak (errencurac), eskerrak, laudorioak, otoitza, promesa. Hitz hurrenkerari erreparatuz gero, bietara aurki daitezke izen ondoko datiboak, eskumatara (a,c,g) zein ezkerretara (b,d,e,f).

Ikusten denez, izen ondoko datibo sintagmak ez dira Lardizabalen lanean bezain urriak, ez hartan bezain mugatuak egitura datibodunak. Aldiz, Lardizabalen lanarekin konparatzen jarraituz gero, askoz ere gutxiago dira Etxeberriren lanetan aurki daitezkeen egitura postposiziodunak. Gehienetan erabiltzen den postposizioa instrumentala da.

(44) a. Saindu particularren Arrosarioaz. Abisua (EZ Man II 173)

b. Litaniez abisu generala (EZ Man II 188)

c. Bideco ontassunez esquerrac (EZ Man II 125)

Eta datibo eta instrumentala biak jasotzen dituen adibideren bat ere bada. ${ }^{21}$ Kasu honetan, eskumatara lerratzen dira bata zein bestea:

(45) Laudorioac lehenik Iainco berari berac ordenatu gaucez (EZ Man I 11)

Bestalde, inoiz ere badira destinatiboa ere erakusten dutenak, eskuma (a,b) zein ezkerretara (c,d) baita honi dagokionez ere:

(46) a. Laneco othoitçac nekhacaleentçat (EZ Eliç I 21)22

b. Itsassoco othoitçac marinelentçat (EZ Eliç 24)

c. Haur ttipientçat othoitçac haurra eri denean (EZ Man II 99)

d. Haur ttipientçat esquerrac sendatu denean (EZ Man II 100)

20. Batzuetan puntu batek bereizten du izen ondoko sintagma izenetik, eta horrek zalantza zor dezake ea benetan IS-ren barruan ote dagoen, baina beste batzuetan ez dago ez punturik ez komarik modifikatzailearen eta buruaren artean bata bestetik bereizten.

21. Testuan zehar ageri diren izenburuak eta aurkibidean ematen dituenak sarritan ez datoz bat. Adibidez, Laudorioac Aitaren presunari izenburua ageri da testuan (EZ Man I 11), eta bere ordez aurkibidean, Laudorioac Aitaren presunari bere obrez eta manuez (EZ Man II 207).

22. Aurkibidean emandakoaren arabera zuzendu dugu izenburu hau. Testuak berez hauxe dakar: Laneco othoiç̧ac nekhaçailleneentçat (EZ Eliç 22) 
Alabaina, lekuzko postposizioen arrastorik ez dago bere lan osoan. Halakoak ezin aurkitzeak, eta, aldiz, instrumental edota destinatibodunak aurkitzeak zerikusia izan lezake izenburuen izaerarekin berarekin, eta goian aipatu ditugun aditzetatik eratorritako izenen gabeziarekin -joanera, itzulera eta abar-.

Ikusten denez, aukeratu ditugun idazle klasiko bietan, diferentziak diferentzia, izen ondoko datibo eta postposizio sintagmak ez dira batere arrotzak, eta neurri batean, gaur egungo prentsan jaso daitezkeen egituren arbasoak dira.

\section{Ergatibo sintagmen agerpena}

Orain arteko lerroetan, datibo eta postposizio sintagmak izan dira gure mintzagai nagusia, eta ergatibo sintagmen aipamena egin dugunean erakutsi dugunez, ezin daiteke halako sintagmarik ageri beste IS bat zuzenean modifikatzen, eta genitiboa beharrezkoa du izen ondoko bihurtzeko. Hori gogoan izan behar du irakurleak, ondoren emango ditugun antzeko adibideetan, ergatibo sintagma izen ondokoa dela pentsa litekeelako. Itxurak, baina, ez gaitu okerreko bidera eraman behar: agerraldi hauetan, sintagma beregainak ditugu, eta ez ISren askotariko modifikatzaileak.

\subsection{Bernard Etxepare eta ergatibo sintagmaren agerpena}

Etxepareren eskaintza hala hasten da:

(47) Erregeren adbokatu bidezko eta nobleari, bertute eta hon guziez konplituiari bere jaun eta jabe Bernard Leheteri, Bernard Etxeparekoak, haren zerbitzari xipiak, gogo onez gorainzi, bake eta osagarri

Linguae Vasconum Primitiae liburuan (1545), prosaz idatzitako sarreraren lehen esaldia da bera, eta bertan ageri zaizkigu elkarren segidan lan honetan aztergai ditugun egituren osagai nagusiak -datibo eta absolutibo sintagma- berritasun esanguratsu batekin: ergatiboaz markatutako sintagma.

Esaldia ez dago izenburu gisa emanik, eta ez da tipografikoki bereizten jarraian datorren testutik -vs. (3.2) atala-. Alabaina, dudarik gabe, testuaren eskaintza da, eta halaxe ulertu behar dela uste dugu. Eredu honetako esaldi bakarra da testu osoan, geroago datozen poesien izenburuetan -gogoratu adibidez, Amoros sekretuki dena, Kontrapas, eta abar-, ez baitago berriro bere aztarnarik.

Ikus dezagun orain esaldi osoa apurka-apurka. Gorainzi, bake eta osagarri izenak dira juntatutako IS-en buru. Analisia erraztearren, izen horietatik bat, gorainzi adibidez, har dezake irakurleak. Buru horren eskumatara bere jaun eta jabe Bernard Leheteri datibo sintagma dugu, eta are eskumatarago, aposizio gisako beste bi datibo sintagma. Prosaren konplexutasuna alde batera, sintaxira begira gogoan izan beharrekoa da, itxuraz bederen, izen ondoko datibo sintagma bat dugula hemen, Bernard Leheteri gorainzi lelopean laburbildu litekeena. Analisia erraztuz, besterik gabe, sintaktikoki nabarmentzekoak diren alderdiak erakutsi nahi ditugu, eta ez prosaren jarioa ezkutatu. Sintaxiaren ikuspuntutik, printzipioz ez dago honainokoan berria den egiturarik. Alabaina, irakurlea konturatuko denez, Bernard Leheteri datibo sintagmaren ondotik ez dator gorainzi izena bera, ez bada Bernard Etxeparekoak ergatibo sintagma, eta bere ondotik, haren zerbitzari xipiak ergatiboz markatutako aposizioa. Hortaz, Leheteri 
Etxeparekoak gorainzi egitura erraztua dugu oinarrian, hasieran datibo eta absolutibodun egitura baino ez zenari, ergatibo sintagma gaineratzen diona. Utz dezagun momentuz gogo onez postposizio sintagma, egitura sintaktikoa areago zamatzen duena -nahiz eta bere agerpena alperrikakoa ez den, ziur aski-.

Ergatibo sintagmaren agerpena bere neurrian ulertu behar da: nahikoa erabilera mugatua dirudi hemen mintzagai dugunak -Etxepareren liburu osoan bat bakarra-. Hori ere ez da oso harrigarria, kontuan hartzen baldin badugu, eskaintzan baino ez dela ageri egitura hau, eta halako eskaintzarik ez dagoela ondoren liburu osoan zehar -goian dagoeneko esan dugun moduan, oso bestelako izenburuak eman zituen gero poesia sortan zehar, gure gaiari dagokionez, adierazgarriak ez direnak-. Dena den, agerraldi bat bakarra izateak ez du bere garrantzia lausotzen: ez dugu ahaztu behar euskal lehen liburu inprimatuko lehen esaldia dela bera, eta izan zirela ondoren ere esaldi hori bezalakoxeak beste egile batzuen idatzietan -ikus (4.2) atala-. Alabaina, hemen, gure ustez, ez dago IS nagusi bat eta sintagma hori modifikatzen duten askotariko sintagmak, ez bada, besterik gabe, sintagma beregainak eta IS bakarrean bildu ezin daitezkeenak. Halako agerraldiak, ziur aski, ez zaizkio (17) egiturari zor.

\subsection{Joanes Etxeberri Ziburukoa eta ergatibo sintagmaren agerpena}

Goian esan dugun bezala, lehena izan arren, ez da Etxepare halako erakusgarriak dituen idazle bakarra. Klasikoak arakatzen hasita, Etxeberri Ziburukoaren Manual devotionezcoaren hasieran ere aurkituko ditu irakurleak orain mintzagai dugun egituraren erakusgarriak. Egitura hau liburuaren aztertzailearen oharrean (a) ageri da lehenik -P. de Axular eta P. de Guillentena dira liburua aztertu eta argitaratzeko aholkua ematen dutenak-; bigarrenik, P. Guillentenak berak, Itsasuko errektorea zenak idatzitako eskaintzan (b), eta hirugarrenik, idazlearen hasierako ohar batean. Hona hemen, hiru agerraldiak, hurrenez hurren:

(48) a. Examinatzailleec Iphizpicua[r]en ordain handiari, Manual hunez iduritu zaienaz. b. Ioannes Etcheberri Doctor Theologo, eta Manual hunen eguilleari bere adisquideac. c. Iracurtcaille devotari eguilleac liburu hunen maneraz abisua (4)

Elicara erabiltceco liburuan ere antzeko egiturak jaso daitezke:

(49) a. Harc berac hari berari berce laudoriozko coplac

b. Etcheberri dotor theologoari orenetaco Salmu baçuen paraphrasa eguiñ duenaren gainean, bere adisquideac laudoriozco copla

Etxeberrik idatzitakoa da lehena (a) eta Tristan de Aphezterenak bigarrena (b). Egileen aipamena egiten dugu erakustearren ez dela Etxeberri bakarrik egitura darabilena, eta liburu hasierako testu horietan, idazle bat baino gehiago baliatzen dela estrategia berberaz.

Hiru esaldi hauek direla eta, hauxe esan dezakegu lehenik eta behin: hirurak ageri direla izenburu gisa emanik, testutik banaturik, eta tipografikoki ere, modu berezian idatzirik. Horrek argiro erakusten du zein den egituraren eremua. Are, liburuaren hasierako testu laburren buruan jasotzen den egitura hau, ez da gero erabiltzen liburuan zehar ageri diren gainerako izenburuetan. Horrek pentsaraz liezaguke forma hauek klixe bati lotzen zaizkiola, eta ez direla, hortaz, emankorrak, baina goiko adibideen joskerari begiratzea baino ez dago ohartzeko klixe bat baino zerbait konplexuagoa dagoela bertan: a) hitz hurrenkera sarriago datibo-ergatiboa 
izan arren -(48b,c) eta (49b)-, badira, ergatibo-datibo hurrenkera erakusten dutenak -(48a) eta (49a)-; batzuetan absolutibo sintagma dugu -abisua eta laudoriozco coplac- eta besteetan, ez da absolutibodunik ageri (48a,b), bere ordezkoa baita ondoren jasotzen den testu osoa; c) oinarrizko hiru sintagmez gain, postposizio sintagmak ere ageri dira-Manual hunez iruditu zaienaz, adibidez-; mendeko perpausak ere tarteka daitezke (46b). Gauzak zeharo sinpletzea litzateke, beraz, esaldi hauek itxuratzen dutena klixe hutsa dela pentsatzea.

Orain arte erabili dugun gaiari dagokionez, kasurik esanguratsuenak beharbada absolutibo sintagma erakusten dutenak dira. Har dezagun eredutzat ondoko hau Iracurtcaille devotari eguilleac liburu hunen maneraz abisua (48c). Irakurtcaile devotari abisua dugu oinarrian, gure lanari izena eman dion izenburua bezalakoxea dena -marinelei abisua-. Datibo sintagma hori eskumatara lerratutako izen ondokoa dela pentsa dezakegu orain artean bezala. Antzera esan genezake postposizio sintagmaz ere: liburu honen maneraz izenaren ondokoa dela esan genezake. Kontua hauxe da orduan: zer ote da eguilleac? Abisua buru duen IS aski konplexu baten osagai bat besterik ez da? Izen ondokoa hori ere? Ez dirudi hala denik. Ergatibo sintagmak sintagma beregaina dirudi, ez abisua ISren mendeko modifikatzailea. Hortik aurrera, egitura osoa nolakoa den zalantzak ditugu. Jon Ortiz de Urbinak eta Patxi Goenagak dioskute elipsiaren argitara ulertu behar direla egitura hauek, baina elipsiaren hipotesia erabiltzen hasiz gero, ikusi beharko litzateke zer ote den ezabatzen dena eta non ezabatzen den egituran. Baliteke aditza eta aditz laguntzailea izatea ezabatzen direnak. ${ }^{23}$ Baldin eta hala balitz, izenburuen elipsi orokorraren argitara aztertu beharko litzateke, eta horrek lan honen mugak zeharo gainditzen ditu.

\subsection{Excurso oso labur bat Leizarragaren izenburuetako elipsiaz}

Ikusten denez, gure jomuga nagusia izen ondoko datibo eta postposizio sintagmak izan arren, horrek izenburu eta abarretan ageri diren bestelako egiturak aztertzera eraman gaitu, tartean ergatibo sintagmak biltzen dituztenak. Lana amaitzeko, azkenik, labur aipatu nahi genuke izenburuetan elipsiari esker sortutako beste estrategia bat, klasikoetan, Leizarragarengan aurki daitekeena, hain zuzen ere. Hona, bere pare bat adibide baino ez ditugu ekarriko, arreta eman digun egituraren erakusgarri gisa.

(50) a. Christ Bethlehemen iayo (Lç Mt 2 tit)

b. Ioannesec Phariseuac reprotchatzen (Lç Mt 3 tit)

Adibide hauetan, argi dago inflexioa dela Leizarragak isiltzen duena. Elipsiak, kasu honetan, ez du zalantzarik sortzen. Estrategia honen arrastorik bat ere ez dago gaur egungo prentsan, baina ez horren aspaldi, ez akaso Leizarragaren eraginpean, halakoxeak irakur zitezkeen gure astekarietan:

(51) a. Lehendakaritza sailak sozialisten agiriari erantzun atzokoan (Eguna, 1987-09-17)

23. Linguae Vasconum Primitiae-ren 1995-eko argitalpenean, ingelesez, frantsesez eta italieraz, bederen, emandako itzulpenetan aditza ageri zaigu esplizituki euskarazko jatorrizko esaldi ustez elipsiduna itzultzeko. Ez, aldiz, gaztelaniaz eta alemanieraz. 
b. Frantzian espetxeratutako ustezko etakideak bukaera eman gose grebari (Eguna, 1987-07-07)

c. EA eta EEk zail jarri PNVri PSOErekin akordioa lortzea (Hemen, 1987-02-13)

Josu Landak buruz buru berretsi digunez, laurogeiko hamarkadan moda bihurtu zen aditz laguntzailerik gabeko prentsa izenburuak idaztea. Joera hori asko zabaldu omen zen ez Deia egunkariaren Egunan bakarrik, baita Eginen eta Hemenen ere. Landak dio Joxean Agirre izan zela erabilera horren kazetari paradigmatikoa. Beste batzuek gogor jo omen zuten erabilera horren kontra, eta Egunkariaren (1992: 47) estilo liburuan, halaxe agertzen da hitzez hitz: "Aditza jartzera joko da beti. Ahalik eta kasu gutxienetan egingo da elipsia. Kutsu militarra Uztailaren 14-ak baino egokiagoa da Kutsu militarra izan zuen Uztailaren 14ak [...] Aditza jartzerakoan, osorik idatziko da, laguntzaile eta guzti. Sekula ere ez: Mitterrand-ek Madrileko akordioa onartu. Horren ordez, Mitterran-ek Madrileko akordioa onartu du."

Itxura denez, benetan eraginkorra izan zen estilo liburuak agindutakoa: azken adibideak bezalakoak guztiz desagertu ziren euskal prentsatik. Eta eurekin batera, garai berean, gorago ikusi berri dugun estrategiara -(4.1) eta (4.2) atalak- makurtzen direnak:

(52) a. Nikaraguak eta Hondurasek errua elkarri (Hemen, 1986-12-12)

b. Gipuzkoako Foru Aldundiak baietz autobideari (Hemen, 1986-01-19)

Estilo liburuko ohar berean gaitzesten direnak. Prentsatik aparte ere, askoz ere lehenagokoa da ondokoa, ETA erakundearen lehen agiriko izenburua:

(53) Euskal Herria'ri E.T.A.'k dei (1964-01-01)

Nekez aurkituko ditu irakurleak halakoak gaur egungo prentsan. ${ }^{24}$ Ez dakigu Leizarragak zer iritziko ote liokeen nagusitu den ildoari. Gure iritziz, prentsak nagusiki erabili dituen estrategia murriztaile samarrekin batera, klasikoa izan denari bidea eman beharko lioke berriro ere.

\section{Ondorioak}

Lan honetan, datiboaren izaera sintaktikoa zein den ebasteko erabili diren irizpideetako bat arakatu dugu: izen ondoko datibo sintagmen egitura. Gurea, egitura hori hobe deskribatzeko ahalegina izan da. Ahalegin horretan erakutsi dugunez, gaiak gramatikaren arreta jaso duen gutxietan, deskribapenak labur samar eta behar besteko xehetasunik gabeak izan dira. Datuak klasikoetatik atera nahi izan ditugu, nahiz eta datu historiko horiek gaur egungoekin ere lotzen eta konparatzen saiatu garen. Bestalde, analisiek erakutsi digute gutxienez badela

24. Horrek ez du esan nahi egitura hau gaur egungo testuetan inon aurkitu ezin daitekeenik. Elizen arteko biblia (Askoren artean 1994), besteak beste, ikusi besterik ez dago horretaz ohartzeko: Jaunak Abrahani dei (Has 12 tit), Jaunak agintzaria Abrahani (Has 15 tit), Lotek bi aingeruei abegi ona (Has 19 tit) bezalakoak nonahi aurki daitezke. Gure mintzagai nagusia izan den egituraren erakusgarriak ere sarri aurkituko ditu bertan jakin-mina duen irakurleak: Filistearrei oharpena (Is 14, 28 tit), Jainkoari bedeinkazio-eskaria (Sal 67 tit), Herriari deia (Sal 81 tit). 
gai berera hurbiltzeko bi modu edo hipotesi: datibo eta postposizio sintagmak izen ondoko modifikatzailetzat hartzen dituena eta bestetik, bereziki eskumatara lerratzen direnen kasuan, ASren periferiako osagaitzat hartzen dituena. Azkenik, datiboa, beste behin ere, egiturazko kasua dela esateko ebidentzia ikusi dugu -(r)en kasu markarekin erakusten duen harremanean.

\section{Aipamenak}

Agirre, Jesus María. 1991. Euskal gramatika deskriptiboa. Bilbo: Labayru.

Albizu, Pablo. 2001. "Datibo sintagmen izaera sintaktikoaren inguruan". In B. Fernández \& P. Albizu (arg.) Kasu eta komunztaduraren gainean. On case and agreement. Bilbo: UPV/ EHU. 49-63.

Albizu, Pablo. 2009. Construcciones inacusativas con dativos posesivos y dativos de interés en vasco: un análisis derivacionalista. Seminario de Lingüística teórica. Madril: CSIC.

Askoren artean. 1994. Elizen arteko biblia. Donostia.

Rijk, Rudolf P.G. de 1988. "Basque Syntax and Universal Grammar." II World Basque Congress. Conference on the Basque Language. I. 69-88. [Birrarg.: Rijk, Rudolf P.G. de. 1988. De Lingua Vasconum: Selected Writtings. ASJUren gehigarriak XLIII. UPV/EHU. 251-270]

Rijk, Rudolf P.G. de 1993. "Basque Hospitality and the suffix -ko." In J.I. Hualde eta J. Ortiz de Urbina (arg.) Generative Studies in Basque Linguistics. Amsterdam: John Benjamins. 145-162. .[Birrarg.: Rijk, Rudolf P.G. de. 1988. De Lingua Vasconum: Selected Writtings. ASJUren gehigarriak XLIII. UPV/EHU. 377-390]

Egunkaria. 1992. Estilo liburua. Donostia: Egunkaria Bilduma.

Elordieta, Arantzazu. 2001. Verb Movement and Constituent Permutation in Basque. Utrecht: LOT.

Etxeberri Ziburukoa, Joannes. 1665. Eliçara erabiltceco liburua. Bordele.

Etxeberri Ziburukoa, Joannes. 1627. Manual devotionezcoa. 2 liburuki (I, II). Bordele.

Etxepare, Bernard. 1545. Linguae Vasconum Primitiae. Bordele. [Birrarg. Euskaltzaindia. 1995].

Euskaltzaindia. 1985. Euskal Gramatika: Lehen Urratsak I. Iruñea: Institución Príncipe de Viana eta Euskaltzaindia. [Birrarg. Euskaltzaindia. 1991].

Fernández, Beatriz. 2007. High and low datives in Basque bivalent constructions, eskuizkribua, Rutgers.

Fernández, Beatriz eta Jon Ortiz de Urbina. 2010. Datiboa hiztegian. Bilbo: UPV/EHU-ko Argitalpen Zerbitzua.

Lardizabal, Francisco Ignacio. 1855. Testamentu zarreco eta berrico condaira. Tolosa.

Leizarraga, Joannes. Iesus Christ gure iaunaren testamentu berria. Hordago. 1979.

Makazaga, Jesús María. 1999. “-kiko atzizki konposatuaz.” In J.C. Odriozola (arg.) Zenbait gai euskara teknikoaren inguruan. Bilbo: UPV/EHUko Argitalpen Zerbitzua. 15-54.

Zabala, Igone. 1999. "Izen-sintagma konplexuak: adjektiboen segidak." In J.C. Odriozola (arg.) Zenbait gai euskara teknikoaren inguruan. Bilbo: UPV/EHUko Argitalpen Zerbitzua. 107-158. 